\title{
Technology and Education: A Study of the Impact of Educational Video Games on Physics Teaching
}

\author{
Yuan Yuan ${ }^{1, \dagger}$, Zhirong Zhang ${ }^{2, *}, \dagger$, Yiming Zhao ${ }^{3, \dagger}$ \\ ${ }^{1}$ Holy Trinity Episcopal Academy, Melbourne, Florida, United States \\ ${ }^{2}$ School of Educational Technology, Shenzhen University, Shenzhen, Guangdong, China \\ ${ }^{3}$ School of International Studies, Southwest University, Chongqing, China \\ ${ }^{*}$ Corresponding author. Email: ${ }^{2} 2018122123 @$ email.szu.edu.cn \\ Those authors contributed equally.
}

\begin{abstract}
Along with the application of science and technology in the teaching and learning process, various game-based learning platform tools such as Nearpod, Kahoot are also becoming increasingly popular. The popularity of such platforms also places a more significant growth in the demand for practical teaching applications via those platforms. However, despite its gaining popularity, scholars have a lack of research and critical data findings on the benefits and problems of applying such game-based learning platforms in the classroom since it is a newly developed instructional technology and just becoming mainstream. Therefore, this study aimed to study students' and teachers' experiences and perceptions of using games/game-based technology in physics classrooms in China to shed light on policymakers and school administrators' problems and challenges of applying more game-based technology into science classrooms.
\end{abstract}

Keywords: educational video games, physics teaching, policymakers

\section{INTRODUCTION}

In recent decades, the fast advancing of technology has brought games to the traditional classrooms, specifical classrooms in China that are traditionally teacher-centered and teacher authoritative. Becky (2001) indicated that "The value of games as a vehicle for teaching concepts while inspiring students is now well accepted at almost all levels of education" [1]. Games are increasingly gaining acceptance in the classroom as they enhance student engagement via their interactive nature [2]. Games can also provide more immediate feedback as compared to the traditional methods such as paper quizzes [3].

Along with the application of science and technology in the teaching and learning process, various game-based learning platform tools such as Nearpod, Kahoot are also becoming increasingly popular. The popularity of such platforms also places a more significant growth in the demand for practical teaching applications via those platforms. More importantly, the new development technology in education and the complex situation with the expansion of COVID-19 during the past two years have also made game-based learning even more popular in both physical in-person and online classrooms as they can play as a significant tool to help students improve learning efficiency. However, despite its gaining popularity, scholars have a lack of research and critical data findings on the benefits and problems of applying such game-based learning platforms in the classroom since it is a newly developed instructional technology and just becoming mainstream. Therefore, this study aimed to study students' and teachers' experiences and perceptions of using games/game-based technology in physics classrooms in China to shed light on policymakers and school administrators' problems and challenges of applying more game-based technology into science classrooms. The following research questions guided this study:

1. What are students' perceptions and experiences on the different games during their physics learning?

2. How much did they understand the functions of different games in their physics learning, and to what degree did they consider them contribute to their physics learning?

3. How much did they perceive the role of games in motivating them to learn physics? 


\section{THE NECESSITY OF INTEGRATING TECHNOLOGY IN SCIENCE EDUCATION}

The nature of science education yields the necessity of integrating more technology-based learning tools in science education classrooms, including game-based learning platforms. Traditionally, science learning is a long and tedious process for many students, especially some science subjects such as physics, as it often includes a variety of formulas and theoretical knowledge systems that need rote memorizations [4, 5]. For example, in physics learning, students often need to memorize the formula as the most basic level of learning physics. Then students need to practice the formulas through repetition to reach the level of physics proficiency. As the subject is studied and explored more in depth, students will often be required to demonstrate strong thinking skills and a spirit of exploration to be able to summarize the relationship between different formulas and finally be able to expand the solutions to the problem.

For most students, the long, tedious, repetitive, rote memorization and practice process is the biggest obstacle for achieving physics proficiency, specifically in the traditional context of practicing in traditional paper-based worksheets. Learning and practicing in traditional paper-based worksheets is often considered boring and monotonous for many students. As a result, students often lose patience and give up before reaching the expected level of physics proficiency. A low level of physics proficiency often leads to lower physics achievement and thus further leads to more frustrations in learning physics via rote memorization and repetition. Therefore, integrating technology-based learning platforms into the physics learning process could potentially solve such problems due to its interactive nature, which could lift the boredom of physics learning.

\section{THE BENEFITS OF INTEGRATING GAME-BASED TECHNOLOGY INTO SCIENCE EDUCATION}

The integration of game-based technology into science classrooms can bring many benefits[6][7][8]. With technological advancement, technology is increasingly integrated into science education in the current environment, especially in many developed countries with better technology infrastructures. In those countries, technology is an integral part of the classroom. Teachers are often used to set up projectors and use some online educational game websites as an integral part of their teaching. Compared to the traditional paperbased worksheets, educational games can provide students with pictorial and interactive scenarios that allow them to relate physics to real-life experiences to understand abstract physics concepts more quickly and visually. Also, such educational games used by teachers present concepts visually, which can engage students in spontaneous, immediate learning and ease students' frustration. Moreover, using educational games in the classroom will also be helpful to improve the efficiency of the classroom when students' engagement is enhanced, and frustration is limited[9][10].

\section{THE STATUS OF INTEGRATING GAME-BASED TECHNOLOGY INTO SCIENCE EDUCATION IN CHINA}

On the contrary, due to the differences in the educational system and the limitation of educational resources in China, most teachers in China still prefer to use the traditional lecture methods that are most likely to be teacher-centered and teacher authoritative. Though the traditional method has its track of success, it is too monotonous. In China's classrooms, teachers usually output knowledge unilaterally to students, which often lacks teacher-student interaction and student-student interaction. In such a unilateral situation, students are easily distracted during the lesson, while educational games can easily keep students engaged and motivated. Distraction, as a result, usually leads to students being unable to grasp the key points and digest them in time, while educational games can provide students immediate feedback. Therefore, game-based technology is an effective tool to mediate teaching and learning in science classrooms.

\section{METHODS}

\subsection{Context and Participants}

This study happened in Shenzhen, China, where the economy and education are developing rapidly as compared to other areas in China. Therefore, this study applied a convenient sampling strategy to recruit participants at the same schools where the authors are studying to complete the interview process. At the end of the participant recruitment process, 10 participants (5 teachers and 5 students) agreed to participate in this study. They agreed to complete the open-ended interview for the purpose of this study. Please see Table 1 for the detailed student participant information and Table 2 for the detailed teacher participant information.

Table 1. Detailed Student Participant Information

$\begin{array}{ll}\text { Grade Location } & \text { Years of } \\ \text { Level } & \text { learning } \\ & \text { physics }\end{array}$

\begin{tabular}{llll}
\hline Student A & 17 & northern China & 5Ys \\
Student B & 21 & southern China & $7 Y_{s}$ \\
\hline
\end{tabular}




\begin{tabular}{|c|c|c|c|c|c|}
\hline Student C & 15 & \multicolumn{2}{|c|}{ southern China } & \multicolumn{2}{|l|}{$2 Y s$} \\
\hline Student D & 18 & \multicolumn{2}{|c|}{ southern China } & \multicolumn{2}{|l|}{$5 Y s$} \\
\hline Student E & 20 & \multicolumn{2}{|c|}{ northern China } & \multicolumn{2}{|l|}{$7 Y_{s}$} \\
\hline & $\begin{array}{l}\text { Age } \\
\text { range }\end{array}$ & $\begin{array}{l}\text { Grade } \\
\text { Level }\end{array}$ & Location & School & ype \\
\hline $\begin{array}{l}\text { Teacher } \\
\text { A }\end{array}$ & $30-40$ & $7-9$ & $\begin{array}{l}\text { Southern } \\
\text { China }\end{array}$ & $\begin{array}{l}\text { Training } \\
\text { institutic }\end{array}$ & \\
\hline Teacher & $40-50$ & 6 & Southern & Primary & \\
\hline$B$ & & & China & School & \\
\hline Teacher & $30-40$ & 7 & Southern & Junior & High \\
\hline C & & & China & School & \\
\hline $\begin{array}{l}\text { Teacher } \\
\text { D }\end{array}$ & $35-45$ & 9 & $\begin{array}{l}\text { Northern } \\
\text { China }\end{array}$ & $\begin{array}{l}\text { Junior } \\
\text { school }\end{array}$ & high \\
\hline $\begin{array}{l}\text { Teacher } \\
\text { E }\end{array}$ & 55 & 12 & $\begin{array}{l}\text { Northern } \\
\text { China }\end{array}$ & $\begin{array}{l}\text { Senior } \\
\text { school }\end{array}$ & high \\
\hline
\end{tabular}

\subsection{Data Sources}

For the purpose of this study, two interviews were designed and conducted to explore both teachers' and students' experiences and perceptions on the use of various educational games.

\subsubsection{Interview for Students}

In the student interview section, we selected students of different ages and asked them about the impact of games on their learning efficiency. Questions covered in the interview include:

- What do you like about the subject of physics? Why or why not?

- What are some difficulties you have encountered in learning physics courses?

- Have you ever played an educational video game (such as a virtual lab) in a physics class or after class?

- Do you think the games in this course are interesting? If so, why do you think courseware with games is more interesting than just text and pictures?
- Do you think these games enhance your understanding of knowledge points? Why?

- Do you think adding teaching-related video games to your physics class will increase your interest in what you are learning? If yes, what aspects of the game increase your interest?

- Do you think the game will motivate you in learning other aspects of the subject?

\subsubsection{Interview for Teachers}

In the part of the teacher interview, we focus on teachers' views on the advantages and disadvantages of educational video games in teaching. The interview questions were designed as follows:

- How do you usually teach physics? What teaching strategies do you usually use in your physics classes? Can you share_something about your_teaching methods and your experience in the educational process?

- How do you think the students in your class are doing in physics? How do students perform in your classroom? What are the students' attitudes towards learning physics in your class?

- Do you usually incorporate some game-based technology (such as Virtual Laboratory) into your courseware? How effective do you think this teaching strategy is for the physics class? (if yes, to Q4; if no, to Q10)

- Under what circumstances would you choose to use the game-base?_How frequently do you use them?

- To replace the teaching model and show the experimental operation

- Introduce some abstract theories

- Interspersed in the courseware, used as a tool to guide group activities

- How do you think students' grades, learning interests and class status change after using the game-integrated courseware? Do you think that students' attitudes and academic performance in physics have changed after using the game? In what specific ways?

- Have you encountered any difficulties in using games for teaching? For example, the resources of games are hard to find, or the game operation is tedious.

- What do you think about the future development of educational e-games?

- Do you think the use of video games has more pros or cons? 
- What are your reasons for not using a gamebased for teaching? What do you think is the disadvantage of integrating video games into the classroom?

- What improvements do you think are needed for game-based to be more useful in the physics class?

\subsection{Data Analysis}

All the interviews were video-recorded and then transcribed verbatim to data analysis. The interviews were conducted in Chinese, and the full transcript was translated into English for further analysis. Inductive and deductive coding strategies were applied in the data analysis process to reveal the patterns and themes across participants.

\section{RESULTS AND DISCUSSION}

\subsection{Theme 1: Most students considered the physics concepts as logical and relatively difficult to understand.}

By analyzing the students' interview transcripts, when they were asked if they liked the subject of physics, eighty per cent of the students said no. By further investigating the perceived reasons they listed, we found that most of them hold the opinion that the physics concepts were too abstract to understand. In addition, that the process of learning physics was boring. For example, Student A mentioned that: "I didn't like it much because the theory of physics was obscure and it is also really logical. I always have a hard time understanding what the teacher is saying in class." Also, student B expressed his opinion that "I think physics is boring because it is too complicated and takes a lot of time to understand the definitions. I just don't like this kind of boring learning process." The responses of both students A and student B indicated that they considered physics concepts difficult to understand. Still, the teaching of physics that they have experienced did not help alleviate the difficulty. Instead, they generally considered physics teaching is boring, which yields the need to incorporate more innovative instructions.

\subsection{Theme 2: Nearly half of the students said they had used the game-based technology and had a positive attitude toward it.}

By analyzing the feedback given by students in questions 3 and 4, we learned that nearly half of the students had been exposed to game-based technology (e.g., game-based websites, software) before at different stages of their physics learning. Students considered that using games in the physics learning process can deepen their impression of the knowledge and make the abstract knowledge visualized so that they can internalize the abstract concepts easier. Some students also think that game-based technology can stimulate their desire for competition with their peers and thus boost their interests and confidence in physics learning. For instance, student $\mathrm{C}$ gave a good explanation for that: "Interesting. I get to operate some virtual physicsrelated equipment on my own, rather than just doing the questions. The games also gave me access to the physics engine. I like the feeling of playing a game, like exploring a new world." Student B also indicated the advantage of the game-based technology in her responses. She said: "I could feel my adrenaline rising during the game, and this competitive approach stimulated my desire to learn more." Students' responses indicated that game-based technology being integrated into the physics classrooms not only presents abstract physics concepts visually that increase their conceptual understanding level. The interactive, competitive nature of game-based technology can also give them the excitement and motivation to learn more.

\subsection{Theme 3: Educational games are considered to be a distraction to students}

Some teacher participants indicated that they didn't incorporate video games or other educational games in class because they believed that games could distract their students. They also indicated that games might change the focus of their class, which reduces the efficiency of their teaching. For example, the teacher who teaches physics in primary school said, "Pupils have difficulties concentrating, and discipline can sometimes be hard to control. The addition of video games can make the situation very unstable." Also, teacher D in high school said, "If students pay too much attention to the novelty of video games, they may ignore the exploration of knowledge itself".

\subsection{Theme 4: Resources for educational games are extremely scarce and untargeted}

Some teachers considered that China's educational game resources are too limited, and the available educational games cannot meet their teaching demands. They also believed that most of the existing game resources are not systematic enough to be used directly. "Sometimes some resources take a lot of time to find, and the resources that are found may not be fully applicable, which need to post-process by ourselves," said teacher $\mathrm{C}$, who teaches physics in a junior high school. "Foreign countries publish some games, so there are problems like translation before they can be used in the classroom." said teacher A from the training institute. This shows that educational video game resources exist in the lack of resources and no targeted features. Teacher E said: "Current educational games need to pay more attention to the design of the system, and 
expanding the impact to attract more users, to play a role in the classroom."

\subsection{Theme 5: Educational games help students deepen their understanding of physics}

Some students said that they have difficulties learning physical courses, and they considered the reasons as the theoretical concepts are too abstract to apply in real study. Student A said, "These are more interesting than regular courseware because they visually address the learning aspect. More images can be provided, as well as flash animations. Theoretical knowledge that exists only in the textbook can be made three-dimensional, and mini-games can be designed for related content, which builds a bridge between theory and the understanding of real-life phenomena." Thus, students considered that games could make physics classes more interesting with boring theoretical lectures and make knowledge less boring.

\subsection{Theme 6: The negative impact of educational games}

Some teachers revealed their worry about educational game addiction. They believed that educational game addiction in children does not happen in total isolation. The negative effects of video game addiction are clear for perceptive individuals to see. Both parents and teachers may notice decreased performance at school coupled with lower grades and failing classes. Because of hours spent playing games, game addicts exhibit fatigue and regularly sleep during school. They may not complete assignments or may not turn assignments in on time. Video game addiction leads to a loss of interest in after school activities, including social clubs and sports. Video game addicts may actually isolate themselves from family members and friends to play video games. Some student participants also indicated that the games result in low-efficiency of study. They have more trouble concentrating on their knowledge.

\section{CONCLUSION}

Data analysis found that students generally had positive experiences and attitudes toward game-based technology. Most of them would like to include more game-based learning technology in the physical classrooms due to its interactive and competitive nature since they consider physics concepts relatively difficult to understand compared to other subjects. On the other hand, the data analysis finds that teachers generally have more of a negative attitude toward integrating gamebased technology into their physics classrooms. They considered it is scarce, untargeted, and likely to distract students. Thus, there is a gap between students' attitudes and experiences toward game-based technology and teachers, who experience the limited uses of gamebased technology in physics classrooms.

Due to the formatting of the educational system as well as the limitation of resources in our country, most teachers prefer to use the traditional lecture method, which ensures the progress of the course but is too monotonous. In Chinese physics classrooms, teachers usually output knowledge unilaterally to students, which often lacks interactivity and leads to students being distracted during the lesson. The traditional classrooms in China were not very interactive and geared toward more and teacher-dominated authoritative teaching, which explains why teachers do not usually prefer educational games that are interactive in nature.

Despite the fact that teachers generally have a negative attitude toward games in the physics classrooms and the authoritative teaching, teacherdominated traditions in China, educational game resources are relatively limited in China, which further limits the wider uses of games in physics classrooms in China. Due to the lack of educational game resources in China, teachers who want to use games to assist teaching will face some restrictions. Foreign game resources may have translation and other problems, which can not be directly applied to class; at the same time, the existing domestic resources are scattered, lack systematic, and can not be associated with the curriculum of primary and secondary schools, so teachers need to spend a lot of time to post-processing the game resources. Thus, we recommend that policymakers and school administrators develop specific task forces to develop more educational game resources within China or import more educational game resources to China with appropriate and working translations. In addition, school administrators should develop more teacher training programs for school teachers on integrating educational games into the classrooms.

\section{REFERENCES}

[1] Becker, Katrin, Teaching with games: the minesweeper and asteroids experience,2001, University of Calgary

[2] KristianKiili,Digital game-based learning: Towards an experiential gaming model, Tampere University of Technology, Pori, Pohjoisranta 11, P.O. Box 300, FIN-28101 Pori, Finland

[3] Andrew Miller, Erin Christensen, Narelle Eather, Shirley Gray, John Sproule, Jeanne Keay,Jeanne Keay, Can physical education and physical activity outcomes be developed simultaneously using a game-centered approach?July 13, 2015 Research Article 
[4] A. Hassard Reverse learning and the physiological basis of eye movement desensitization[J] Medical Hypotheses, 1996, 47(4)

[5] DeVaughn Croxton and Gerd Kortemeyer Informal physics learning from video games: a case study using gameplay videosDeVaughn Croxton and Gerd Kortemeyer 2018 Phys. Educ. 53015012

[6] Nataly Riaño Carmona. Implementation of a Social Constructivist Educational Model and a Significant Learning for the Development of Video Games for the Teaching of Colombia Caribbean Art[C]., 2019.

[7] Mark W. Olofson, Meredith J.C. Swallow, Maureen D. Neumann TPACKing: A constructivist framing of TPACK to analyze teachers' construction of knowledge[J] Computers \& Education, 2016, 95

[8] Kandler Lukas, Tscholl David W, Kolbe Michaela et al. Using educational video to enhance protocol adherence for medical procedures[J] British Journal of Anaesthesia, 2016, 116(5)

[9] Calderone Jessica R., Hobbs Laura K., Chin Ryan et al. Implementing an Educational Video to Improve Residents' Knowledge of Nutrition[J] Journal of the American College of Surgeons, 2020, 231(4S2)

[10] Anne Nileshni Fernando, Gemma Sharp Genital Self-Image in Adolescent Girls: The Effectiveness of a Brief Educational Video[J] Body Image, 2020, 35 